rich field as the cracks were too numerous and as, moreover, the soil inside the clods tended to become pulverized readily even under light touch. The results of analyses which will be detailed elsewhere indicated in general that the differences in physical properties between corresponding crack and clod samples were less marked in the well-drained field than in the eroded field. With the latter, there was greater uniformity between surface and sub-soil samples taken along the cracks than from the clods. Thus, the main contrast between the well-drained and poorly drained fields was in the depth to which good tilth existed below the surface.

These observations could be explained as principally due to the fact that, by means of these cracks, considerable quantities of soil material are periodically carried down from the surface to lower depths within the soil, both on account of the hot summer winds and by the early June rains ${ }^{2}$. It is also probable that the first showers of the monsoon are followed by the swelling up of the colloidal masses from be$l_{0}{ }^{3}$. There is thus a pronounced circulation of the soil material, a result similar to that brought about by cultivation. This 'self-ploughing and sub-soiling' is so intense that mechanical cultivation often becomes ineffective. Experiments carried out for more than five years at this Institute ${ }^{5}$ have shown conclusively that summer cultivation with or without inversion to different depths before Kharif sowing is not necessary for the rain-sown, unmanured cotton crop. It has been shown similarly that preparatory cultivation on the black soils of Koilpatti (S. India) ${ }^{6}$ and in the Sudan ${ }^{7}$ is superfluous and may, at times, be decidedly harmful ${ }^{8}$. Even in temperate and cooler regions the effect of the traditional thorough cultivation has begun to be doubted. Thus, at Rothamsted", it has been shown that cultivation in excess of that needed to keep down the worst weeds does not confer any further benefit and may even result in a reduction in yield. It would, of course, be useful to adopt summer ploughing in a weed-infested field such as, for example, in the eradication of kans (Saccharam spontaneum) and dhub (Cyanadon dactylon), for it is found that hot-weather ploughing exposes and kills the roots ${ }^{10}$.

An interesting observation was that the concentration of soluble salts in the soil along the cracks was always higher than in the corresponding sample from the clods ( $c f$. Mosseri) ${ }^{11}$. This would suggest the possibility of reclaiming saline lands by promoting crack formation, which will be followed by the washing down with the first rains of the deleterious salts along the crack edges.

Another significant observation related to the rather wide difference in the swelling capacity of the surface and sub-soil samples taken along the cracks, this difference being somewhat less pronounced in the poor field. In either field, the samples from clods did not show any appreciable difference in this property. It would appear that the greater difference with depth in this respect may account for the higher degree of cracking in the well-drained field.

It may be concluded from the foregoing that the development of soil cracks during summer fallow must be promoted. This can be done (i) as already stated, by avoiding, or at any rate reducing to a minimum, cultivation during summer fallow, and (ii) by allowing crop plants to remain in the fields for a certain period (say, until about the beginning of May) after harvesting operations are over. In the latter case, the standing plants will tend to put out ratoon growths. This will be accompanied by deeper penetration of roots followed by new lines of cracking. I have observed that the juxtaposition of crop rows with field cracks have confirmed that standing crops greatly facilitate soil cracking. A possible objection to this practice is that the ratoon crop may deplete the soil of its fertility; while this may be true in some measure, it should be pointed out that if the standing crop is removed by about the middle of the hot season, the recuperative power of the soil during the hot period, coupled with the advantages of better cracking, may offset this depletion. If, however, such crops have had, during their normal period of growth, any disease or insect attack, it may be necessary to pull them out as soon as harvest is over.

It is of interest to compare here the beneficial effects on crop growth resulting from (1) building up of the loose surface soil artificially to different thicknesses ${ }^{12}$, and (2) application of 'fired' soil in the subsurface regions ${ }^{7},{ }^{13}$. In heavy soils, the wide cracks formed as a result of extreme variations in swelling and shrinkage is indeed Nature's efficient method of heating and weathering the sub-soil layers. This uniformity with depth in the surface soil will obviously promote greater bacterial activity with consequent production of mucus, which aids in the formation of water-stable aggregates 14, 15.

The advantages of cracking during any one season will admittedly be small, but the cumulative effect over prolonged periods will no doubt be appreciable enough to increase the fertility of a field. Besides, in a waterlogged field, the development of these cracks, followed by the ingress of the surface soil through them, will improve the permeability and drainage conditions in the field.

\footnotetext{
${ }^{1}$ Bouyoucos, G. J., Soil Sei., 18, 103 (1924).

${ }^{2}$ Greene, H., J. Agric. Sci., 18, 518 (1928).

"Vageler, P., "An Introduction to Tropical Soils" (London: Macmillan, 1933), p. 179. "Howard, A., "An Agricultural Testament" (Oxford, Univ. Press,
1940), p. 138.

${ }^{5}$ Annual Report, Institute of Plant Industry, Indore (1937).

- Ayyar, V. R., Ayyar, S. S., and Tirumalachari, N. C., Madras Agric. $J_{., 2}$, 28, 69 (1940).

7 Annual Report, Gezira Agric. Res. Ser., Sudan Govt. (1937).

${ }^{\circ}$ Viswa Nath, B., Agric. and Live-stock in India, 8, 9 (1938).

- Russell, E. W., and Keen, B. A., J. Agric. Sci., 28, 212 (1938); Keen, B. A., J. Min. Agric., 45, 645 (1938).

${ }^{10}$ Howard, A., Agric. J. Ind., 22, 39 (1927).

${ }^{11}$ Cited from Keen, B. A." "The Physical Properties of the Soil" (London, Longmans, 1931), p. 144.

${ }^{12}$ Sreenivasan, A., NATURE, 148, 144 (1941).

${ }^{13}$ Sreenivasan, A., and Aurangabadkar, R. K., Soil Sci., c0, 449 (1940).

${ }^{14}$ Peele, T. C., J. Amer. Soc. Agron., 32, 204 (1940).

${ }^{15}$ Martin, J. P., and Waksman, S. A., Soil Sci., 52, 381 (1941).
}

\section{REBUILDING GREAT BRITAIN}

$T$ HE Reconstruction Committee of the Royal Institute of British Architects, which has already published five interim reports dealing with planning and amenities, war-time housing, building legislation, reconstruction of the architectural profession and legislation affecting town and country planning in Great Britain, has now issued a first general statement of conclusions, which in soms respects provides an interesting parallel to the recent report of the Scott committee.

Dealing first with human needs as a foundation for reconstruction, the statement points out that from the point of view of physical reconstruction, the 
essential needs of the individual are suitable work in clean, healthy and cheerful surroundings and a convenient and attractive home, forming part of a community capable of evoking local patriotism and civic pride. The most essential public needs for physical reconstruction are a firmly established agriculture, a prosperous, well-located industry, and an elficient system of transport. As regards the practical and æesthetic needs, the public is right in expecting and demanding that the opportunity afforded by post-war reconstruction shall not be thrown away; buildings and towns must be both convenient for use and pleasant to live in. A civic sense has been slowly but firmly growing up in the people, one form of which is seen in the demand that the slum areas should be no longer tolerated and in regarding the effect of war damage in these areas as an opportunity for total reconstruction. In another form it is seen in the determination to check ribbon development, because that constitutes an offence to the eye, and also in the positive demand that cities and towns should be better to look at and better planned.

In outlining a national plan to meet these needs, the statement points out that assurance is required that the Government's positive policy will deal with individual as well as public needs, and this must be demonstrated by the creation of machinery to produce a national plan as well as to execute it, by the creation of the plan and by its execution. Of these four positive acts the last cannot be contemplated until after the War, but the difficulties in undertaking the other three in war-time must be overcome, at least to the extent of producing the general lines of each before the end of hostilities.

With regard to the machinery of planning, the statement points out that a national authority is essential to obtain a national plan, and at least four Government departments will be deeply involved. Unless all the departments concerned are amalgamated into one huge department, the national planning authority must be so devised that it has the power to co-ordinate the proposals of the various departments and to over-rule the views of any single department when necessary for the sake of the plan as a whole. Some parts at least of the plan will be such that neither private enterprise nor local authority will be able to execute them, and a central executive body will be required to ensure the execution of such work. Accordingly, in addition to a national planning authority and a national planning commission, a development commission will also be requirad. This commission should be made responsible for ensuring the smooth working of the plan in all developments, whether executed by itself, by Government departments, by local authorities or by private enterprise. It would also be responsible for providing local authorities and public utility companies with the necessary credit for the execution of local schemes. In this connexion attention is directed to the Tennessee Valley Authority as a precedent for public development.

In regard to planning authorities, the organization of the whole would presumably consist of a central planning national authority with its regional officers, and groups of local authorities to prepare the local or sub-regional schemes.

A national code of legislation should be compiled to cover the whole of Great Britain, administered from a single office in each locality. This national code should be in three parts, the first dealing with planning for human needs, or what might be termed a code of living standards. The second would deal with structural standards and the third with the financial provisions which will be necessary to achieve these ends.

It is suggested that the code of living standards might be in two parts dealing respectively with standards of amenity which might be advisory, not compulsory, and with health and safety precautions, which should be mandatory. Under this national code, only one application should be necessary for the approval of plans, but submission of plans for approval should be compulsory for all types of buildings. In addition, the appointment of a national building board is visualized, as outlined in a previous interim report.

In regard to the organization of the building industry, co-ordination of the main groups of the industry, the employers, the operatives, professional bodies and the manufacturers and distributors of building materials can best be achieved through the machinery of a central council which might form a liaison with Government departments. So far as technique is concerned, it is essential that those adopted should provide good building with the utmost possible economy as well as the maximum output, and a proper balance between first cost and cost of maintenance.

Surveys already carried out by the Committee indicate that public control of the building industry must continue after the War, and the techniques adopted in building will affect and be affected by the public policy on imports, transport, etc. Coupled with centralized control, the Committee therefore strongly recommends centralized research, expanded and made independent of outside donations by a sufricient Treasury grant. This centralized research should be under the charge of the Building Research Organization.

In regard to finance, the Committee urges that in drawing up its plans for reconstruction, the Government should relieve local authorities of regions of the financial burden, simplify the machinery for dealing with private interests which may be affected, and arrange for the dispatch and distribution of the resources of the building industry in whatever manner seems best for the national interest. With regard to filling in the plan, it is suggested that all land without exception should be publicly controlled, whether publicly or privately owned.

The great building programmes will be so profoundly affected by any changes in the location of industry that local authorities will only be able to make tentative estimates of their needs until Government policy on this subject is formulated. In the existing large towns or 'conurbations', the need for the centralization is generally agreed, and building of a certain number of new satellite towns is complementary to this decentralization. Regrouping within the boundaries of existing towns is as important as decentralization, and new towns should, when possible, be developed from existing small towns or villages.

A local improvement fund for each district is recommended and a very close relation should exist between the housing and town planning committees in an area. Housing should form part of a well-conceived plan for re-equipping the country, and in that it should incorporate standards fulfilling the desires and requirements of the population, should be able to call for the best technical advice and 
knowledge available. The selection of suitable architects requires careful attention. The post-war housing needs cannot be estimated, but the position facing the building industry must be handled on a national, not a local, scale, and only by careful plan. ning ahead can the post-war housing needs be met. The emergency and the long-term programmes must fit into a national scheme which takes account of the future redistribution of industry and of methods of construction. There is no suggestion that the provision of housing by private builders should be discouraged, provided excessive profits on land and buildings are eliminated and that standards both in design and construction are reasonably good. A national policy for house production should be formulated to co-ordinate the work of the various house-building agencies and constitute more even distribution of work and results. Research into consumer needs should also be encouraged.

The final section of the statement deals with the importance of the architect's contribution, both in modern planning and in the public control of the appearance of buildings, and it is stressed that it is essential that every planning authority should employ a well-qualified architect as a principal officer directly responsible to that authority.

\section{LEAD-CALCIUM TEST CASTINGS}

$\mathrm{C}$

LOSE control of the calcium content is required sheath. This is not easily attainable because the calcium content is small and a variable amount is lost while the alloy is molten, despite the special techniques used to minimize air contact. Conventional methods of determining this loss are slow and costly. A new procedure described by G. M. Bouton (Bell Lab. Rec., 20, No. 10 ; June, 1942) arises from Bell Laboratory studies of lead-calcium alloys which have shown that the surfaces of ingots, chill cast with little agitation, become progressively duller with increasing calcium content. Fissuring then sets in and leaves bright areas exposed, depending in extent on the amount of calcium present. Under controlled conditions these markings provide a quick, accurate measurement of the calcium content.

The sample is melted in a small iron crucible, the lip of which is brought close to the mould before pouring, to minimize exposure to the atmosphere. The mould itself is an iron plate with a tapered depression about $4 \mathrm{in}$. long and $\frac{5}{8} \mathrm{in}$. wide, milled on its surface. To ensure reproducible results, casting is done in a 'Cellophane' chamber through which passes air of known carbon dioxide and moisture content. since both affect the results, they are first removed by passing the air over potassium hydroxide and calcium chloride. A definite percentage of each is then replaced in the casting chamber, and the melt poured. Representative figures are 50 per cent humidity and 0.02 per cent carbon dioxide. Decreasing moisture and increasing carbon dioxide make the surface brighter, and vice versa. Alloys of calcium content outside the range of the method may be tested by diluting or enriching them with lead-calcium alloys containing appropriate amounts of calcium. This method of determining the calcium content in cable sheath is reliable and more rapid than chemical analysis or metallographic techniques.

\section{FORTHCOMING EVENTS}

(Meeting marked with an asterisk is open to the public)

Saturday, October 3

Grologists' Associatron (at the Geological Society of London, Burlington House, Piccadilly, London, W.1), at 2.30 p.m.-Dr. David Burlington House, Piccadilly, London, W.1), at 2.

Tuesday, October 6

Chadwick Pubuic Lecture (at the Royal Society of Tropical Medicine and Hygiene, 26 Portland Place, London, W.1), at 2.30 p.m. - Sir Leonard Hill, F.R.S. : "The Interrelation of Clothing and ShortFriday, October 9

Institution of Mechanical ENGINEers (at Storey's Gate, St. James's Park, London, S.W.1), at 5.30 p.m.-Mr. E. Watson Smyth: "The Training Activities of the Ministry of Labour".

\section{APPOINTMENTS VACANT}

AppuICArions are invited for the following appointments on or before the dates mentioned:

HEaD OF ENGINEERING DRPaRTMENT (MEchanicaI AND ELECTRICAL) in the School of Mines and Technology, Treforest-The Director of Education, Glamorgan County Hall, Cardiff (October 12),

LECTURER IN FIECTRICAI ENGINEERING-The Secretary, University College, Dundee.

\section{REPORTS and other PUBLICATIONS}

\section{(not included in the monthly Books Supplement) Great Britain and Ireland}

Report of the Committee on Amenities and Welfare Conditions in the Three Women's Services. (Cmd. 6384.) Pp. 58. (London: H.M. the Three Women's Services. (Cmd. 6384.) Pp. 58. (London: H.M.
Stationery Office.) 1s. net. Proceedings of the Royal Irish Academy. Vol. 48, Section A, No. 1 : The Band Spectrum of Manganese Hydride, MnH, 1 : Structure of the 25677 and 26237 Bands. By T. E. Nevin. Pp. $42+3$ plates. $3 s$. Vol. 48, Section A, No. 2: The Energy of the $182 s^{\mathrm{s}} \mathrm{S}$ State of the Helium Atom and related Two-Electron Ions. By T. S. Wheeler. Pp. 43-53. 1s. Vol. 48, Section B, No. 3: The Albite-Schists of Antrim and their Petrogenetic Relationship to Caledonian Orogenesis. By Doris L. Reynolds. Pp. 43-66. 1s. $6 d$. Vol. 48, Section B, No. 4: River Liffey Survey, 5 : Growth of Brown Trout (Salmo trutta L.) in Alkaline and Acid' Waters. By Arthur E. J. Went and Winifred $\mathbf{E}$. Frost. Pp. 67-84. 1s. (Dublin: Hodges, Figgis and Co., Ltd.; London: Williams and Norgate, Ltd.)

\section{Other Countries}

Proceedings of the California Academy of Sciences, Fourth Serics. Vol. 23, No. 33: Redescription of Three Species of the Polychetous Family Polynoidæ from California. By Tage Skogsberg. Pp. 481-502 +plate 43. (San Francisco, Calif: : California Academy of Sciences.) [149 Reports of the Great Barrier Reef Committee. Vol. 5. Pp. ivt (10s. [179 Indian Association for the Cultivation of Science. Annual Report for the Year 1941. Pp. 38. (Calcutta: Indian Association for the
Cultivation of Science.) Indian Forest Bulletin No. 110 (Utilisation, New Series) : A Short Note on Wood Preservation for Users in India. By Dr. D. Narayanamurti. Pp. v+22+5 plates. (Dolni: Manager of Publications.) 2 annas ; 1s. [189 Memoirs of the Geological Survey of India. Palæontologia Indica, New Series, Vol. 30, Memoir No. 2: Some Permian Corals from the Plateau Limestone of the Southern Shan States, Burma. By Dr. Stanley Smith. Pp. iii $+24+2$ plates. (Calcutta: Geological Survey of India.) 1.8 rupees; $2 s .3 d$.

Forest Research Institute, Dehra Dun. Indian Forest Leatlet No. 13: Safe Working Stresses for some Important Indian Timbers. By V. D. Limaye. Pp. il +11 . Indian Forest Leaflet No. 14: A Preliminary Note on the Suitability of Indian Woods for Battery Separators. By M. A. Rehman and S, M. Ishaq. Pp. ili +4 . Indian Forest Leaflet No. 15: Studies on Adhesives, Part 1: Ground-Nut Protein Adhesives for Plywood. By D. Narayanamurti, V. Ranganathan and P. K. Basu Roy Chaudhuri. Pp. ii +9 . Indian Forest Lcafiet No, 16. Studies on Adhesives, Part 2 : Ground-Nut ProteinFormalde murti and Kartar Singh. Pp. il 13. Indian Forest Leaflet No. 17: Interim Report on the Sulability of some Indian species for Aircraft Construction- M. Limaye. Pp. ii +3 . 4 annas; 64 . Indian Forst Lealet other Rotenone Bearing Vegetable Insecticides, their Occurrence and Possibilities of Cultivation in India. By T. P. Ghose. Pp. ii +9.4
annas; 6d. (Dehra Dun: Forest Research Institute.)

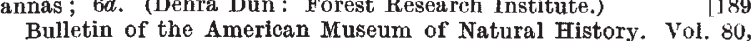
Art. 1: Results of the Archbold Expeditions, No. 45: Mammal Notes from Highland County, Florida. By A. L. Rand and Per Host. Pp. 